\title{
Why Composition Matters
}

\author{
Andrew M. Bailey ${ }^{1}$ and Andrew Brenner ${ }^{2 \star}$ (C) \\ ${ }^{1}$ Division of Humanities, Yale-NUS College, Singapore and ${ }^{2}$ Department of Religion and Philosophy, Hong Kong Baptist \\ University, Hong Kong \\ *corresponding author. Email: andrew.t.brenner@gmail.com
}

\begin{abstract}
Many say that ontological disputes are defective because they are unimportant or without substance. In this paper, we defend ontological disputes from the charge, with a special focus on disputes over the existence of composite objects. Disputes over the existence of composite objects, we argue, have a number of substantive implications across a variety of topics in metaphysics, science, philosophical theology, philosophy of mind, and ethics. Since the disputes over the existence of composite objects have these substantive implications, they are themselves substantive.
\end{abstract}

Keywords: Composition; mereology; substantivity; metametaphysics; material objects

\section{Introduction}

Some disputes just don't matter. It doesn't matter whether the number of electrons is odd; nothing hangs on that question. And, so, disputes about whether the number of electrons is odd are themselves trivial, nonsubstantive, unimportant, shallow, or defective in their very subject matter. ${ }^{1}$

Ontological disputes, let us say, are disputes about what there is. They concern theses like:

Comp: There are composite objects.

Plato: There are abstract objects.

Soul: There are thinking immaterial objects.

Many philosophers think ontological disputes are defective. ${ }^{2}$ In particular, disputes over Compdisputes about composition and whether there are any composite objects at all-have come under fire. In this article, we defend such disputes.

A standard complaint about ontological disputes (and those over Comp, in particular) is that they are merely verbal. Another is that they are trivially easy to settle. Yet another is that the disputes are defective because they are irresolvable. Disputants have, of course, found ways to develop or rebut these charges. ${ }^{3}$ In this article we are concerned with the complaint that ontological disputes (and those over Comp, in particular) are defective because they are unimportant in their subject

\footnotetext{
${ }^{1}$ Bracket concerns about whether quantum field theory implies that there aren't any particles such as electrons, and whether electrons are "individuals." The important point to note is that, assuming there are a determinate number of electrons, it simply doesn't matter whether that number is odd or even.

${ }^{2}$ The detractors of ontological disputes-and of disputes about Comp in particular-are legion. Prominent among them are van Fraassen (2002), Putnam (2004), Bennett (2009), Hirsch (2011), Thomasson (2007, 2015), and Willard (2013). See Sider (2009) for discussion and for citations of even more detractors.

${ }^{3}$ See, e.g., Dorr (2005), Sider (2011, chap. 9).

(C) The Author(s), 2020. Published by Canadian Journal of Philosophy. This is an Open Access article, distributed under the terms of the Creative Commons Attribution licence (http://creativecommons.org/licenses/by/4.0/), which permits unrestricted re-use, distribution, and reproduction in any medium, provided the original work is properly cited.
} 
matter. Compare: a dispute over whether the number of electrons is odd wouldn't obviously be merely verbal, and it wouldn't obviously succumb to trivial settlement. Nevertheless, such a dispute would be defective because it simply doesn't matter whether the number of electrons is odd. (Of course, it may also be defective because it is irresolvable. $)^{4}$

Bas van Fraassen complains that many metaphysical disputes, including the dispute over Comp in particular, are impotent "with respect to real questions of any importance" $(2002,4,9)$. Similarly, James Maclaurin and Heather Dyke contend that, in contrast to such important subjects as ethics, politics, and religion, the question of whether there are composite objects "can perhaps be said to play an important part in the lives of a relatively small group of academic philosophers and their students" $(2012,300) .{ }^{5}$ Similar sentiments are even more frequently voiced informally, especially by philosophers who do not specialize in metaphysics. ${ }^{6}$

Concerns about mere verbality, triviality, and the concern that ontological disputes are irresolvable have already found ample expression and rebuttal in the literature. By contrast, philosophers have made little effort to evaluate the complaint that ontological disputes, and the dispute over Comp in particular, don't matter. ${ }^{7}$ We shall rectify this situation by bringing this new complaint to the fore and-more to the point-showing that it fails.

One might here offer a negative defense of ontological disputes by addressing the reasons which have been offered on behalf of the claim that ontological disputes don't matter. Though we'll later have something to say about the detractors, answering their concerns is not our central strategy. ${ }^{8}$ We shall, instead, offer a direct argument that the detractors are wrong. Our argument is, if you like, a positive defense.

\section{Argument}

Our positive defense takes this form:

Substance: Disputes about Comp have substantive consequences.

Closure: If a dispute has substantive consequences, then it is substantive in its subject matter. Therefore, disputes about Comp are substantive in their subject matter (from Substance and Closure).

\footnotetext{
${ }^{4}$ Here and in the sequel, we'll treat "is important," "is substantive," and "matters" as synonymous. That a dispute enjoys this condition does not imply that we should, all things considered, engage it. For more on that, see our discussion of which disputes are "worthwhile" in section 4.

${ }^{5}$ See also Unger (2014, chap. 6). Unger claims that disputes over Comp are "concretely empty," and it seems that they would therefore lack import. On interpretive difficulties with Unger's arguments, see Hawley (2014).

${ }^{6} \mathrm{Cf}$. the following entry in a popular series of web comics: https://existentialcomics.com/comic/339.

${ }^{7}$ There are exceptions. Graham's (2014) defense of the importance of ontological disputes complements our own, although he does not specifically address Comp. Graham argues that the significance of a theoretical dispute is measured, in part, by whether that dispute has implications for other theoretical issues. To say that a dispute is "significant" in this sense is to say that it is "worth taking seriously, or paying attention to, or investing time and effort in" (Graham 2014, 68). On the basis of this criterion, Graham defends the significance of two sorts of ontological disputes: disputes over the existence of concrete possible worlds and disputes regarding coincident material objects. A similar defense is in Hofweber (2016, chaps. 1.4.3, 7, 9.3). According to Hofweber, disputes about Comp are important because if there are no composite objects then many of our beliefs are false. And, in particular, many of our beliefs that involve or require our own existence will be false, since if there are no composite objects then presumably we do not exist. Unfortunately, Hofweber's defense of these claims is tied up with controversial meta-ontological theses about quantification. He also doesn't make the sorts of explicit connections we make in this paper between disputes over Comp and other substantive philosophical disputes worth caring about. Baron (2018) argues that the study of metaphysics is valuable for many of the same reasons that the study of pure mathematics is valuable. Giberman (2018) argues that we should care about disputes regarding the metaphysics of properties and persistence over time. Korman (Forthcoming) addresses the question "Why care about what there is?" But the question which concerns Korman isn't quite the question which concerns us. The question that concerns Korman is "Why care about what there is, as opposed to merely caring about what there ultimately is?"

${ }^{8}$ Indeed, a negative defense of this sort would be difficult, since the sentiment we aim to attack is, as noted above, expressed more in informal social contexts than in detail and in print.
} 
The main target of our argument-Professor Unaware, if you like-is the critic who is heretofore unaware that Comp connects to so many other domains and has substantive consequences in them (we'll give examples shortly). Professor Unaware regards fussing over Comp as a rather insular affair, unconnected to other disputes.

Professor Unmoved, by contrast, is aware that disputes over Comp connect with many other disputes, at least as generally understood by their participants, but Unmoved denies that their target phenomena really do require composition and, so, denies that the disputes in fact implicate Comp in that way. We hope to make philosophers like Unaware more aware. We do not aim to refute Unmoved for, as we see things, Unmoved might be more a critic of composite objects than of disputes over the existence of composite objects. ${ }^{9}$ Here's why. Unmoved's hypothesis that the target phenomena discussed in some dispute don't require composition (and thus that their existence doesn't imply Comp) is compatible with thinking that disputes over Comp matter. In fact, that hypothesis finds an easy home within a rejection of Comp and within a philosophical program that assigns some importance to rejecting Comp. ${ }^{10}$

Are there actual living philosophers like Unaware? We will not attempt to mind read here, but our argument will show that there shouldn't be any. ${ }^{11}$

Our argument is valid, so our task now is to explain and defend the premises in turn.

\section{Composition and its connections}

Our argument for Substance exploits the consequences of Comp or its denial. Disputes about Comp, as it turns out, impinge on a variety of substantive and perennial questions that are important in their subject matter.

It is not always obvious whether some dispute that superficially seems to turn on Comp really does turn on Comp. Some philosophers say that sentences that seem to posit or presuppose the existence of composite objects can sometimes be true even if there are no composite objects, just as sentences like "the Sun moved behind the elms" can be true even if the change in the relative position of the Sun and the trees is due to the movement of the Earth, rather than the Sun. ${ }^{12}$ Others disagree. ${ }^{13}$ We'll not intervene in that debate. How, then, do we tell whether some dispute really turns on the resolution of the dispute over Comp? Principles aren't obvious; we take things on a case-by-case basis. The disputes we discuss below are all cases in which we are strongly inclined to think that the truth or falsity of Comp really does impinge on the truth or falsity of the positions staked out in the disputes. Sometimes this is because disputants involved in those disputes explicitly maintain that their view requires the existence of a certain sort of object, and explicitly maintain that that object is composite. What's more, these explicit pronouncements are made "in the ontology room" (Van Inwagen 1990, chap. 10) and, so, should be interpreted as staking out a position regarding composition. Other times it just seems clear to us that there is no way to understand

\footnotetext{
${ }^{9}$ There may also be other paths to Professor Unmoved's position, of course; those are beyond the scope of this paper.

${ }^{10}$ Perhaps, for example, the mereological nihilist (who denies that there are any composite objects) and the mereological antirealist (who rejects all mereological ideology — cf. Cowling [2014]), would contend that no real-world phenomena need to be understood in terms which require composite objects. But they may very well still think that the dispute over the existence of composite objects is a substantive dispute. What's more, while they maintain that no real-world phenomena need to be understood in terms requiring composite objects, they may nevertheless concede that certain live interpretations of or metaphysical theories regarding some phenomena do require composition (a view we'll exploit below).

${ }^{11}$ Thanks to an anonymous referee for suggesting that we explicitly distinguish between Professors Unaware and Unmoved in this way.

${ }^{12}$ Van Inwagen (1990, chap. 10) and Horgan and Potrč (2008). Van Inwagen doesn't actually deny Comp, but he doesn't believe in many of the composite objects many pretheoretically accept (in particular he thinks that the only composite objects that exist are organisms). Nevertheless, he maintains that "outside of the ontology room" many sentences that seem committed to composite objects are true, even if "inside the ontology room" many of those sentences are false.

${ }^{13}$ Merricks (2001, chap. 7).
} 
various positions in some dispute without interpreting them as requiring the existence of composite objects.

We'll give five brief examples, and then explore another in some detail. Each example offers independent support for Substance; if any succeeds, the premise is true. In each case, we will briefly say why resolving the target dispute crucially turns on Comp.

\section{3.a. Quantum entanglement}

Quantum entanglement is often thought to involve some sort of "holism" or "nonseparability." It is controversial how exactly we should understand these purported features of entanglement. For our purposes, it is enough to note that they are often characterized in mereological terms, as involving composite objects of a certain special sort, such as "entangled wholes." ${ }^{14}$ Perhaps this is loose talk or to be interpreted as involving only, say, "things arranged entangled whole-wise." But the philosophers we have in mind explicitly argue that this interpretation of quantum entanglement won't work, and that entanglement should be understood in terms requiring composition. ${ }^{15}$ On those views, a live and well-supported scientific hypothesis-that quantum entanglement occursrequires not only that Comp is true but that some items together compose a very special sort of object, an "entangled whole." Perhaps that's not right, and quantum entanglement doesn't actually require composition. We will remain neutral on that question. But that some philosophers or scientists advance models that require composition is strong evidence, we think, that the question of when composition occurs is implicated in the interpretation of the phenomena in question. Even if the target phenomena don't themselves plainly implicate Comp, certain models or interpretations of them do.

\section{3.b. Species}

One major dispute within evolutionary biology and the philosophy of biology concerns which unit(s) of selection is the primary locus of natural selection. Hierarchical models (those models of natural selection which take so-called "higher-level" entities such as groups or species as the units of natural selection) are sometimes claimed to require the existence of certain special sorts of composite objects (e.g., species, conceived as composite objects). ${ }^{16}$ Again, the views in question appeal to the existence of objects which are explicitly claimed to be composite. Proponents of these views do not merely talk loosely in terms involving composite objects, in a way which might be compatible with there being merely "things arranged species-wise" (or whatever). So, Brogaard:

"The genes found in cells are not members of the cell, and the cells that constitute an organism are not members of the organism. Cells and organisms are wholes with parts. Since wholes with parts are mereological sums of some sort, cells and organisms are mereological sums. If species taxa are like cells and organisms in the relevant respect, they, too, must be sums" (2004, 225-26).

Brogaard ultimately concludes that species are, like organisms, mereological sums. Brogaard and other proponents of this sort of view explicitly contrast their view with a conception of species as classes or sets, and Brogaard herself discusses whether species are best described using classical extensional mereology. So, they seem to be well aware of salient alternatives to their metaphysical hypothesis concerning species, and they seem to be firmly situated "within the ontology room."

\footnotetext{
${ }^{14}$ See, e.g., Maudlin $(1998,55)$ and Healey $(2013,56)$.

${ }^{15}$ Morganti (2009, 2013), Schaffer (2010), Calosi and Tarozzi (2014), Calosi and Morganti (2016), Ismael and Schaffer (2020). For critical discussion of all of these arguments, see Brenner (2018, sec. 3).

${ }^{16}$ Ghiselin (1974), Hull (1976, 1978, 1980), Gould (2002, 602-8, 673-74), Brogaard (2004). For a critical discussion, see Brenner (2018, sec. 4).
} 
We suggest, then, that they be taken at face value when they claim that species are composite objects. On this view, another live and well-supported scientific hypothesis requires that there be a very special sort of composite material object. We remain neutral on the question of whether this interpretation of natural selection is correct. The important point is that this interpretation of natural selection cannot be correct unless Comp is true. The question of whether composition occurs is implicated in the question of how we should interpret natural selection.

\section{3.c. Philosophical theology}

Some philosophical models of the Christian doctrine of the Trinity rely on there being some object composed of one or more persons of the Trinity, or rely on one or more persons of the Trinity being composed of something else. ${ }^{17}$ If there aren't any composite objects, as those who deny Comp maintain, then these models of the Trinity are nonstarters for metaphysical, rather than purely theological, reasons. We take no stance on the question of whether the Trinity really should be interpreted in terms which require composition. But we maintain that the models of the Trinity we have in mind ineliminably involve composition. The models are not compatible with there merely being "persons arranged Trinity-wise" (or some nonspatial analogue). A model developed by Jeffrey Brower and Michael Rea, for example, contends that the three persons of the Trinity are distinct but nevertheless composed of the same underlying material, just as a statue and the lump of matter of which it is made are said to be distinct but composed of the same underlying material. This model cannot survive the rejection of Comp. Its central analogy (to composite objects such as statues and lumps of matter) would have no purchase at all, there being no such things as statues and lumps of matter. What's more, it is composition that unites the three persons into one God, for each person is said to overlap a common part-the divine nature. This mereological overlap is what preserves monotheism despite the distinctness of the divine persons. ${ }^{18}$ So, it is composition that allows this model of the Trinity to satisfy two crucial desiderata which are prima facie difficult to reconcilenamely that in the Trinity there are three persons and yet one God. ${ }^{19}$

\section{3.d. Philosophy of mind}

Some philosophers of mind think that the circumstances under which certain sorts of phenomenal or intentional states would or would not be instantiated are connected to the circumstances under

\footnotetext{
${ }^{17}$ Brower and Rea (2005). Moreland and Craig advance a model on which the persons of the Trinity together compose a whole and sum it up thus: “... it seems undeniable that there is some sort of part-whole relation obtaining between the persons of the Trinity and the entire Godhead” $(2009,39)$. It would be very surprising, we think, if Moreland and Craig's model of the Trinity could be correct on this point but nothing entered into any proper part-whole relations. Three persons compose a Godhead only if there are composite things-if Comp is true. This is evidence that the model of the Trinity here in view does, in fact, turn on Comp. Not all models of the Trinity deploy composition, of course, and we don't claim that the doctrine itself obviously hinges on Comp; there is room here for disagreement. So, Plantinga (2007): "Just how we are to think of the Trinity is of course not wholly clear; it is clear, however, that it is false that in addition to each of the three persons of the Trinity, there is also another being of which each of those persons is a part."

${ }^{18}$ Consider the theory that, though there are two things on the pedestal (a statue and a lump of clay), there is only one material object there because the statue and lump have enough proper material parts of the right kind in common (one version of this theory appears in Rea [1998]; see also Lewis [1993]). This theory might have some plausibility-but not if nothing has any proper parts. So also for the Trinitarian model in view; without overlap-without Comp-it collapses.

${ }^{19}$ Whether mereological models of the Trinity are correct will bear on other matters in philosophical theology. Some theists (al-Ghazâlî, Maimonides, Aquinas, and others) maintain that God is absolutely simple. But models of the Trinity that construe God as composite seem incompatible with such simplicity. For example, Aquinas writes that "There are many ways of showing that God is altogether simple.... Secondly, everything composite is subsequent to its components and dependent upon them; whilst God, as we have seen, is the first of all beings [Ia. 2, 3]" (Aquinas, Summa Theologioe Ia 3, 7; 1964, 41, 43). The question of whether divine simplicity is correct will have broad ramifications of its own. It is, for example, the linchpin of much of Aquinas's theological system.
} 
which composition occurs. ${ }^{20}$ Such philosophers maintain, for instance, that things cannot collectively instantiate phenomenal or intentional states except insofar as they compose something that instantiates those phenomenal or intentional states. This claim is thought to have important implications for how we should think about influential thought experiments in the philosophy of mind, including the Chinese nation and Chinese room thought experiments. ${ }^{21}$ If there could be such things as Chinese nations (enormous but scattered wholes composed of billions of people), then they pose deep questions for philosophers of mind. If there couldn't be any such things, then a unified reply may be given to a host of influential thought experiments in the philosophy of mindfor example, the contention that the Chinese nation would not be conscious can be supported by noting that there isn't any such composite object as the Chinese nation. ${ }^{22}$ So, disputes regarding the circumstances under which composition occurs (including disputes over Comp) may turn out to have substantive and surprising consequences in the philosophy of mind. Again, we take no stance regarding the question of whether these philosophers are correct, and the question of when and where composition occurs really is tied up with the question of when and where phenomenal or intentional states are instantiated. But it surely matters whether these philosophers are correct, in part because, as we've noted, it will affect how we think about thought experiments such as the Chinese nation and Chinese room thought experiments. And, so, the question of whether/when composition occurs is potentially connected with a wider range of disputes than we might initially think.

\section{3.e. Social ontology}

A dispute within social ontology and the philosophy of the social sciences more generally is whether social groups and their constituents enjoy part-whole relations. ${ }^{23}$ In this case, those who say that social groups and their constituents are related by part-whole relations are not speaking loosely, in such a manner that the social groups can exist even if they are not thought of as composite objects. Rather, the philosophers we have in mind explicitly contend that social groups should be thought of as composite objects. But if there are no composite objects at all, then there are no composite social objects either. So, if Comp is, after all, false, a wide swath of theories in social ontology and the social sciences-theories that deploy composite social objects-are thereby false as well. And the extent to which there are composite objects will constrict the range of permissible theories. If the conditions for composition are relaxed (as when, for example, any items whatsoever compose another), then there are plenty of composite social objects to play various theoretical roles-courts composed of lawyers, nations composed of citizens, unions composed of workers, and so on. If the conditions for composition are more strict (as when, for example, only rigidly bonded objects compose another), then there are not nearly so many candidates to play those theoretical roles. So, disputes about the truth of Comp-and related disputes about the precise extent of composition-bear on important questions in social ontology and the social sciences. Again, we do not claim that social groups really must be understood in terms requiring composition. Rather, our point is that certain models of the metaphysics of social groups really do require composition in order to be correct. And those interested in the metaphysics of social groups will surely care whether these models are correct.

\footnotetext{
${ }^{20}$ See van Inwagen (1990, sec. 12), Olson (2007, 188-93), Bailey (2016), and Dowland (2016).

${ }^{21}$ See especially van Inwagen (1990, 118-19) and Bailey (2016, sec. 2).

${ }^{22}$ What philosophers who discuss the Chinese nation (and similar examples) don't always notice is that it is by no means obvious that there could be such things as Chinese nations in the first place. If there couldn't be such things in the first place-if Comp is necessarily false, as many nihilists maintain-then reasoning about them crucially involves counterpossibles: reasoning about what would be the case were some impossibility actual. Here, then, the modal status of Comp is relevant not just to the first order dispute ("can computers think?") but to a correct statement of what is even happening when conducting that first order dispute ("are we dealing with possibilities or impossibilities when doing the Chinese nation thought experiment?").

${ }^{23}$ See, for example, Ruben (1983), Copp (1984), Hawley (2017).
} 
These five examples each independently support our contention that disputes about Comp are entangled with substantive disputes across seemingly unrelated fields. For the premise Substance to fail, all five examples must fail. Absent a case against each, however, we think some confidence in the premise is in order. Ubiquitous appeals to the existence and properties of composite objects, inside and outside philosophy, assure this result.

\section{3.f. Personal ontology}

We'll now consider another example in a little more detail. This will provide even more evidence for Substance.

As it turns out, disputes about Comp intersect with substantive disputes about the metaphysics of human nature. For if Comp is false, then a whole range of views in the metaphysics of human persons are also false. For example, if Comp is false and there are no composite objects, then there are no organisms, no brains, no cerebral hemispheres, and no four-dimensional objects composed of temporal parts (we suppose here that if there are such things as organisms, brains, and so on, they are composite). ${ }^{24}$ And so we are not any of these things; we are not (contra the usual materialist views) organisms, nor are we brains, and so on. Virtually every materialist—naturalism friendlyanswer to the question of what we are is ruled out by the falsity of Comp, since virtually every materialist answer to the question of what we are identifies us with a composite physical object of some sort. ${ }^{25}$ Disputes about Comp, then, have substantive consequences for the question of what we are and, in particular, for the question of whether we are wholly material beings. ${ }^{26}$

Whether we are wholly material is, of course, an old question. It is also itself of some importance, for it bears on the success of naturalism and its materialist or physicalist specifications. Those specifications, and so naturalism itself, would be disconfirmed should we turn out to be partly or wholly immaterial. And naturalism itself is, we note, the very paradigm of a nontrivial, substantive, and deep philosophical matter. Its status is relevant to topics ranging from institutions ("Should universities fund paranormal research?") to religion ("Am I the sort of thing that could survive death?") to medicine ("Can the ordinary tools of science be used to promote human flourishing or are special techniques required?"). These are questions everyone cares about and, plainly, they matter.

Implications of disputes over Comp extend further still into matters of practical ethics. For example, consider animalism, the thesis that we are human organisms (as opposed to, say, immaterial souls or mere brains) ${ }^{27}$ If Comp is false then animalism is false too, since animalism identifies us with composite human organisms. ${ }^{28}$

\footnotetext{
${ }^{24}$ This assumption is widely endorsed, but at odds with the view defended in Contessa (2014) and Goldwater (2015). For compelling critical discussion, see Wilkins (2016) and Long (2019).

${ }^{25}$ Van Inwagen (1990, 72-73), Dorr and Rosen (2002, sec. 6), Olson (2007, 198), Sider (2013, sec. 7), Brenner (2017), and Gilmore (Manuscript) all recognize this but do not draw the main meta-ontological lesson of this article.

${ }^{26}$ For more on the content of materialism about human persons and its broader metaphysical significance, see Bailey (2020).

${ }^{27}$ Van Inwagen (1990), Olson (1997), Snowdon (2014), and Bailey (2015).

${ }^{28}$ Compare two theories: (i) There are human animals, we are them, and human animals are composed of various smaller things (cells, say). (ii) There are human animals, we are them, but human animals are not composed of any smaller things; animals are, rather, simple. Animalists, as a matter of sociological fact, overwhelmingly favor (i); this is no bias or prejudice. (i) is, in fact, much more plausible than (ii). Our claim here is not that it is very plausible that there are composite animals. It is, rather, that given what's in common between theories (i) and (ii) — given that there are human animals and that we are them - it is overwhelmingly likely that animals are composite items. A quick review of one popular argument for animalism is helpful. The Thinking Animal Argument (as in Olson [1997, chap. 5; 2003]) selects for consideration one living, breathing organism that's sitting in your chair, and argues that you are that one thing (since you are one in number, it has to be one in number too; the argument presupposes this is not a case of many-one identity). For if you weren't that thing, untoward consequences would follow-ontological overpopulation and such. But what living breathing organism is there in the vicinity of your chair for you to be except one that is about yea high, that has feet, that can be seen in the mirror over there, and so on? Next step: a single living, breathing thing that is about yea high, that can be seen in the mirror over there, and so on-would certainly seem to have parts
} 
But animalism has practical and ethical consequences. Given animalism, you probably shouldn't step into the teletransporter in the hopes that it'll take you places, for example. For whatever information it transmits about your mind or body, it's doubtful that it actually moves the organism you are from one place to another. ${ }^{29}$ For the same reason, you probably shouldn't be confident that "uploading" your mind onto a computer would allow you to survive the death of your body. ${ }^{30}$ For on animalism, it isn't plausible that merely emulating a particular brain and its associated mental states in a computer would preserve the existence of the organism you are. Consider, too, the ethics of abortion. A prominent argument in favor of the prima facie moral impermissibility of abortionthe future-like-ours argument (Marquis 1989)_maintains that abortion is prima facie morally impermissible because it deprives fetuses of valuable futures. This argument requires that the fetus is identical to the person that eventually succeeds it, ${ }^{31}$ and that identity finds its most natural home in animalism. ${ }^{32}$

So, the truth or falsity of Comp has implications for the truth or falsity of animalism, which in turn has implications regarding other practical and ethical concerns.

Turn from animalism to another important view in personal ontology. One traditional motivation for the Buddhist nonself doctrine is mereological nihilism (the denial of Comp). ${ }^{33}$ Above we've noted one way mereological nihilism might support the nonself doctrine: if there are no composite objects, then we can thereby rule out many of the possible answers to the question of what we are. ${ }^{34}$ Ultimately, the proponent of the nonself doctrine maintains that we aren't anything at all: selves do not exist. ${ }^{35} \mathrm{We}$ do not claim that mereological nihilism entails that selves do not exist. Even if mereological nihilism is true, we might be something other than composite objects—for example, we might be mereologically simple immaterial souls. But, again, mereological nihilism supports the nonself doctrine by ruling out most of the views regarding personal ontology that philosophers actually endorse. And, at any rate, many philosophers would contend that we have good reason to think that if we exist then we are composite objects rather than simple objects (if, for example, our being simple requires substance dualism and we have good grounds to reject substance dualism).

Among its proponents, the Buddhist nonself doctrine is generally thought to have soteriological and ethical implications. For example, it is alleged to reduce suffering and fear of death in its proponents. It is also alleged to force us to apply equal moral consideration to the welfare of others as we apply to our own. ${ }^{36}$ These claims should be disambiguated. On the one hand, we have two normative claims: the nonself doctrine should reduce our fear of death, or should lead us to concern

(hands, feet, cells, whatever). One could deny that there is any such composite; that's fine. But it would be a strange denial indeed for the philosopher who insists that you are that one living thing sitting in your chair that breathes and has feet and so on.

${ }^{29} \mathrm{Cf}$. van Inwagen (1996). One, but not the only, route to this conclusion is via the claim that animalism implies that we have biological (and not merely psychological) criteria of identity over time.

${ }^{30}$ Not as fanciful as it may sound; see Sandberg (2013).

${ }^{31}$ For a cautionary note, see Conee (1999).

${ }^{32}$ Olson (1997, chap. 4) and McMahan (2002, chap. 4). Also worth mentioning in this context is the dispute regarding whether or not the developing fetus is a part of its mother (Kingma [2019]). We doubt that this issue should inform our assessment of the ethics of abortion. Nevertheless, it is an issue which some philosophers regard as substantive and interesting. And the question of when, or whether, composition occurs is of obvious relevance to this question about the metaphysics of pregnancy.

${ }^{33}$ For discussion, see Siderits (2015, chap. 4).

${ }^{34}$ Contemporary mereological nihilists tend toward eliminativism about persons for precisely this reason. See, e.g., Rosen and Dorr (2002, sec. 6) and Sider (2013, sec. 7).

${ }^{35}$ Buddhist proponents of the nonself doctrine traditionally maintain that while it is ultimately true that there are no selves, it may still be conventionally true that there are selves (for discussion, see Siderits [2015, chap. 1]). Buddhist proponents of mereological nihilism would generally say something similar about composite objects: while it is ultimately true that there are no composite objects, it is conventionally true that there are composite objects (this point is illustrated in, e.g., the famous discussion of the chariot in Questions of King Milinda [1890]). For simplicity, we ignore these slight complications in the main body of this article.

${ }^{36}$ For discussion of both of these alleged consequences of the nonself doctrine, see Siderits (2015, chap. 5). 
ourselves with the welfare of others. On the other, we have two descriptive claims: advocates of the nonself doctrine will, in fact, have a reduced fear of death, or will in fact have greater concern for the welfare of others. Though Buddhist proponents of the nonself doctrine have traditionally endorsed both the normative and the descriptive claims, here we are particularly interested in the normative claims. ${ }^{37}$

For illustrative purposes, consider the alleged connection between the nonself doctrine and the normative claim that we should be just as concerned for the welfare of others as we are concerned for our own welfare. In his Bodhicaryāvatāra, Sāntideva offers the following influential line of thought in support of this normative claim. My suffering is a bad thing. In general, I should aim to reduce my own suffering. But it would be arbitrary to suppose that I should reduce my own suffering and not the suffering of others. One purported relevant distinction between my own suffering and the suffering of others is that my own suffering is my suffering, and those who suffer have a special obligation to reduce their own suffering. Here is where the nonself doctrine comes in:

"The continuum of consciousnesses, like a queue, and the combination of constituents, like an army, are not real. The person who experiences suffering does not exist. To whom will that suffering belong? Without exception, no sufferings belong to anyone. They must be warded off simply because they are suffering. Why is any limitation put on this? If one asks why suffering should be prevented, no one disputes that! If it must be prevented, then all of it must be. If not, then this goes for oneself as for everyone." ${ }^{38}$ (Śāntideva 1995, chap. 8, secs. 101-3)

If the nonself doctrine has the normative implications that its proponents generally claim it has, and if the truth of Comp bears on the truth of the nonself doctrine, then the truth of Comp bears on the truth of these normative claims. And it seems clear, furthermore, that the normative claims at hand are substantive indeed.

We conclude that the case for Substance is strong. Disputes about Comp have substantive implications across a variety of disputes in metaphysics, science, philosophical theology, philosophy of mind, and ethics.

\section{The closure of substantivity}

And because those disputes matter, so, too, does Comp. Or so we shall now argue. Our argument relies on this principle:

Closure: If a dispute has substantive consequences, then it is substantive in its subject matter.

Closure proposes a sufficient condition for substantivity. The condition is by no means necessary. Indeed, for all we say here, disputes over Comp are, in addition to being instrumentally substantive, noninstrumentally substantive-interesting in their own right and independent of their consequences.

It's hard to say what makes a philosophical dispute substantive in its subject matter. But suppose a dispute between various views is indeed substantive; any philosophical position that rules out a wide swath of those views would seem to itself be substantive in its subject matter, too. Trivial or shallow positions that are unimportant in their subject matter don't have such consequences. ${ }^{39}$ Compare: Gregor Mendel's experiments involving pea plants might initially seem unimportant

\footnotetext{
${ }^{37}$ For some recent empirical evidence bearing on the descriptive claims, see Bartels, Kvaran, and Nichols (2013) and Nichols et al. (2018).

${ }^{38}$ Note the mereological nihilism in this passage, implicit in Saantideva's assumption that such things as queues and armies are not real.

${ }^{39}$ For defense of a general "closure of substantivity" principle that implies Closure, see Greco (2015). Graham (2014) deploys a similar premise.
} 
except for those interested in breeding pea plants. But once one realizes that those experiments unlock the mysteries of genetic inheritance, and so unleash important insights regarding evolutionary processes, one sees that the experiments are important after all. The experiments are important because they have important implications. Similarly, if it turned out that something interesting or deep or substantive really did follow from the thesis that the number of electrons is odd (if it followed from that thesis that nothing was morally right or wrong, say), then disputes about electron cardinality would themselves prove interesting and substantive in their subject matter. They would, because of their connection to other things, matter. The same goes for disputes about Comp.

Does a dispute, no matter how zany, become substantive simply by bearing on something important? We think so. To stave off appearances to the contrary, it is helpful to distinguish between whether a dispute is substantive and whether it is worth our time. It matters whether the Earth is flatfor geography, world history, astronomy, philosophy of science, optimal flight paths, and so on..$^{40}$ But it doesn't follow that disputes about the shape of the Earth are worth our time. A host of factors figure into an overall assessment of whether a theory is to be taken seriously and whether we should argue over it: its prior probability, its posterior probability on a given body of evidence, its fruitfulness or parsimony, and so on. If disputes over the flatness of the Earth are defective or not worth our time, it is not because they don't matter; it's because they've already been settled. (We would model this as the target hypothesis being overwhelmingly improbable on a wide body of shared and indisputable evidence.) Perhaps disputes over Comp are similarly settled; perhaps the denial of Comp resembles a flat Earth hypothesis in this respect. But note: nothing we've said contradicts that assessment. Our claim is, rather, that debates over Comp are substantive. They matter.

So, Closure is quite plausible. And given Substance, the conclusion of our argument follows: disputes about Comp are substantive in their subject matter.

Our argument so far is interesting enough, but it may be augmented toward an even stronger conclusion. Substantivity comes in degrees. Even among various disputes that matter, some matter more than others. We propose this extension, then, of Closure: if a dispute has many substantive consequences, then it is very substantive in its subject matter. The evidence we've offered in the preceding section supports the antecedent of that conditional; disputes about Comp bear on a great many disputes of real consequence and import. And, so, we suggest that disputes about Comp are very substantive in their subject matter.

\section{Consequences}

We'll close by briefly taking stock, addressing a few stray concerns, and drawing out what follows.

\section{5.a. Varieties of substantivity}

We may distinguish between substantivity in subject matter and in method. Our argument suggests that disputes about Comp enjoy the former; it says nothing about the latter. Our argument does not show that there are strong reasons for or against Comp, that we have evidence for or against Comp, that philosophers have pursued questions about Comp with the right tools, that such philosophers are not talking past each other here (as in "merely verbal" disputes), or even that we have any hope of discovering the truth about Comp. It shows only that disputes about Comp matter; the truth about Comp is a matter of some significance.

\footnotetext{
${ }^{40}$ The point of the example is that mattering in the target sense can peel away from being worthwhile, all things considered. We do not claim that disputes over Comp matter as much as those about the flat Earth hypothesis. Perhaps they don't. (Though this may change. In a future where "uploading" is cheap and viable, the metaphysics of material objects-including Compmight become as practically important as fuel economy.)
} 
Is our conclusion, despite its modesty, interesting or newsworthy? We think so. It is easy to see why some philosophical disputes matter. The correct social epistemology of trust and expertise, for example, has obvious consequences regarding the aptness of relying on the judgements of epidemiologists. It is much less easy to see that something of importance could hang in the balance when it comes to metaphysics. And, so, it is tempting to conclude that metaphysics, for that reason and in contrast to ethics or epistemology, say, just isn't worth our time-disputes over Comp, even more so. Our argument shows that this tempting line of reasoning is incorrect. It uncovers what kind of stakes are at play in disputes over Comp. Some are purely theoretical-within and beyond metaphysics proper. And some are practical-they concern what we should do. That metaphysics could be like ethics or epistemology in this respect is a surprising result.

\section{5.b. Whence the resistance?}

We've concluded that composition matters.

Why would anyone have ever thought otherwise? One reason, we suspect, is that discussions of Comp occur at a level of abstraction that masks connections with matters that more plainly command our attention and care. At that high level of abstraction, the dispute concerns whether a proper parthood relation is ever instantiated, whether or when unity arises from diversity, and so on, with perhaps a detour into even more abstract meta-ontological disputes regarding, e.g., whether the quantificational expressions used to frame the dispute over Comp are "joint-carving." 41 This is heady business. And when the discussion is not so abstract, it can easily appear to mostly concern proper metaphysical interpretation of the mundane and quotidian features of everyday life. The metaphysician might wonder, for example, whether tables (it's almost always tables) exist, or whether there are merely "things arranged table-wise."

We feel the pull of these concerns. The way that disputes over Comp typically unfold gives the impression that the matters under dispute are either abstruse or mundane and therefore isolated from anything of deep and real interest. ${ }^{42}$ We've shown how disputes over Comp are in fact connected with disputes worthy of our care, disputes that concern matters which are neither banal nor, we think, overly abstract. The main goal of our paper, then, has been to make explicit the connection between Comp and some of the issues with which it intersects. We hope to dispel the air of unreality that attends abstract discussions about the nature of parthood and to dispel the air of triviality surrounding seemingly dull and pointless debates over household furniture.

Despite everything we have said, some still can't shake the sense that debates over composition just aren't important in their subject matter. They're a game. It doesn't matter who's right or wrong. We've argued directly that this impression is mistaken. That is the main point of our paper. In addition to all that, we've offered one hypothesis about the origins of that impression.

Here is a slightly more speculative diagnosis.

Knowledge skeptics - who think we don't know anything at all-say the darndest things. Taken at face value, their views strictly imply that we don't know why the Twin Towers fell, whether HIV causes AIDS, or whether vaccinations work. It's puzzling that skeptics still get jobs. We read and cite their books dutifully. We take them seriously; they are not mere cranks. Perhaps our toleration is to be explained along these lines: skeptics don't really mean the things they say. It sure sounds like they mean something mad, but, in fact, they mean something else. There is some charity in this interpretation. But there is not-charity too, for in saving the skeptic from charges of madness, the interpretation at hand implies that disputes over skepticism are considerably less important than they might initially seem. They don't concern the mad thing; they're about something else. And it is far from obvious that something else matters at all. Maybe chatting with skeptics, then, is just a game.

\footnotetext{
${ }^{41}$ Cf. Sider (2011, chap. 9).

${ }^{42}$ In this connection, see Ross et al. $(2007,14)$ who say composition is a topic where "... metaphysicians have constructed a herm[e]tically sealed world in which they can autonomously study their own special subject matter.”
} 
We speculate that something similar happens in metaphysics. Nihilists about composition say the darndest things: that there aren't any composite objects, for example. Taken at face value, their views strictly imply that there aren't any such things as rockets (so NASA never made any rockets that went to the moon) and that there are no rare books in the Beinecke Rare Book \& Manuscript Library. It's puzzling that these nihilists get jobs. We read and cite their work. Why? Perhaps it's because we suspect that nihilists, too, don't really mean the things they say. Like the skeptics, they mean something else, something that just doesn't matter. So, chatting with them is, after all, just a game.

Our argument points in a different direction. We could bend over backwards to interpret nihilists as saying something benign and unimportant-true, perhaps, but boring. Or we could accept that their views are important, if true. And then we could simply accept or deny those views on the basis of the best arguments. ${ }^{43}$ This is how we'd react to conspiracy theories about NASA or the Beinecke. Why not here as well? Perhaps the thought is that nihilism, interpreted as an interesting and important thesis, is just mad and, so, clearly false. Some do react this way to nihilism. But this is not the concern that we aim to address in this paper. If you think that nihilism is obviously false, then we direct your attention to extant responses to that concern on behalf of nihilism. ${ }^{44}$

\section{5.c. Two reactions}

Our argument typically prompts one of two contradictory reactions. ${ }^{45}$ The first is that none of the disputes discussed in our argument turn on Comp. The second is that the disputes we discuss obviously do turn on Comp, so those who regard the debate over Comp to be nonsubstantive must have a special sense of "substantive" in mind, one not addressed here.

We have engaged the first of these reactions directly throughout this paper. But what about the second? Well, we don't think it is obvious that Comp is implicated in so many other disputes. That is a link that requires argument to uncover. We suspect that those who think that disputes over Comp are unimportant have probably not appreciated the extent to which they intersect with so many others. ${ }^{46}$ This dismissive attitude, our argument shows, comes at a price: it requires either a dismissive attitude toward all these other disputes, or commitment to the view that those disputes don't connect with Comp after all. We doubt that those who are dismissive of disputes over Comp generally realize that they'll have to take on one or both of these two commitments. Nor would they be comfortable doing so.

Now, perhaps you'll suspect that all of these other disputes which we claim intersect with the dispute regarding Comp are unimportant in their subject matter (it has to be all; if only some are unimportant, our argument still succeeds), or that the dispute over Comp doesn't really impinge on those other disputes. We have no knockdown refutation of these suspicions. But we would like to emphasize two points.

First, the fact that Comp is connected with so many other disputes across so many fields of inquiry (ethics, philosophy of biology, etc.) supports the view that disputes over Comp themselves have wide-ranging implications. At the very least, given the sheer number and variety of connections we've identified between Comp and other substantive disputes, it seems to us very doubtful

\footnotetext{
${ }^{43}$ In this connection, see Brenner (2015a, 2015b, Forthcoming), Korman (2016) and Rettler (2018).

${ }^{44}$ Van Inwagen (1990, chapd. 10-11), Rosen, Dorr (2002, sec. 5), Merricks (2001, chap. 1), and Sider (2013; especially secs. 2-5).

${ }^{45}$ Thanks to an anonymous referee for raising this issue explicitly.

${ }^{46}$ For example, recall that Maclaurin and Dyke (2012) cite the dispute over Comp as a metaphysical dispute of dubious value. But Maclaurin and Dyke also cite philosophical disputes regarding the nature of species (293), and disputes regarding the unit of selection (300), as examples of naturalistic metaphysics, whose importance they do not call into question. They don't seem to realize that disputes about species and the unit of selection crucially implicate Comp. Our argument draws from the same Hull paper (1978) cited by Maclaurin and Dyke, a paper which argues that species should be thought of as mereological wholes. We think Hull is correct to connect Comp and questions about species, and our argument corrects Maclaurin and Dyke's apparent (and perhaps ironic) oversight.
} 
that the dispute over Comp is entirely barren, in the sense that the truth or falsity of Comp has no substantive implications.

Second, suppose that one or more of the disputes we discuss do not really turn on the status of Comp. There may nevertheless remain a sense in which the dispute over Comp is substantive insofar as it is indirectly integrated with these other substantive disputes. ${ }^{47}$ For example, it may be suggested that those who regard species as a salient unit of selection and as composite objects do not really thereby commit themselves to the existence of composite species, and so do not really thereby commit themselves to a position in the dispute over Comp. This attitude toward talk of "species as composite objects" requires a controversial meta-ontological position; it requires that we do not take the explicit pronouncements of the existence of "species as composite objects" by philosophers and biologists at face value. Perhaps this meta-ontological position is defensible; we lack the space here to consider it in detail. But note that even if this meta-ontological approach is correct, the dispute over Comp would nevertheless be integrated in an indirect manner with the dispute over species as composite objects. Given this integration, a thorough assessment of the "species as composite objects" thesis would require taking stock of the fact that Comp's status is a potentially relevant consideration.

\section{5.d. Critics answered}

Our central task, again, is not to answer the critics. But our positive argument does, we think, show where some go wrong. As we noted earlier, Maclaurin and Dyke write that the question of whether there are composite objects "can perhaps be said to play an important part in the lives of a relatively small group of academic philosophers and their students" (2012, 300). But that a question only interests a small number of people doesn't imply that disputes regarding the answer to that question don't matter. One reason to think that a dispute matters is that it intersects with a number of other disputes which matter-a condition that can be satisfied even if overlooked by many and even if many don't care. But Maclaurin and Dyke also argue that nonnaturalistic metaphysics (metaphysics which, in principle, has no observable implications) is lacking in value because "as an intellectual endeavour, it can have no practical benefit to anybody. This is to say that universals, tropes, possible but non-actual worlds, etc., cannot be harnessed for practical effect. In particular, it can make no difference to science which of a range of metaphysical theories is true" (299). We have seen, however, that disputes over Comp impinge on a wide variety of other substantive matters. In that sense, then, engaging in the dispute over Comp can have at least one benefit: it can help us make progress in these other substantive disputes. We have even seen that the dispute over Comp has life or death consequences which are of plainly practical importance. For example, would you like to survive death? Then you might consider "uploading" your mind into a computer. But before you do so, you'd better have some idea about whether you are the sort of thing that can survive uploading. And coming to terms with that requires engaging Comp. As for whether the dispute over Comp has any implications for science specifically, we have seen that it does-or, at any rate, we have seen that the dispute over Comp intersects with disputes in the philosophy of biology, the philosophy of physics, and the philosophy of the social sciences. ${ }^{48}$

\section{5.e. The way forward}

We began by wondering whether ontological disputes matter, giving Comp as one example of a potentially important ontological dispute. Our argument has been in the affirmative. We have thus

\footnotetext{
${ }^{47}$ Thanks to an anonymous referee for helpful discussion here.

${ }^{48}$ Maclaurin and Dyke might here reply that in drawing out these connections, we've shown that debates over Comp are in fact exercises in "naturalistic metaphysics" and so not subject to their objections to nonnaturalistic metaphysics. Fair enough, we say: naturalistic or not, Comp matters.
} 
struck a blow not just for Comp, but for ontology and metaphysics. The lessons from our argument extend further still. It's not as though metaphysics is the only field in philosophy that finds audiences skeptical of its value, after all. ${ }^{49}$ Our main argument suggests a general way to show how a given field matters or has import: lay bare its connections to other things of real import. Perhaps this can't go on forever; some things have to simply matter themselves, and not just instrumentally and because they connect to other things. We close, then, by highlighting a question worthy of future inquiry: What makes a dispute noninstrumentally or intrinsically important? ${ }^{50}$

Acknowledgments. Thanks to Bradley Rettler and anonymous referees for helpful critique and feedback. Thanks also to the Singapore Ministry of Education for funding in support of this research.

Andrew M. Bailey is associate professor of humanities at Yale-NUS College.

Andrew Brenner is assistant professor in the Department of Religion and Philosophy at Hong Kong Baptist University.

\section{References}

Aquinas, Thomas. 1964. Summa Theologie, Volume 2: Existence and Nature of God (Ia. 2-11). Translated by Timothy McDermott O.P. New York: McGraw-Hill.

Bailey, Andrew M. 2015. “Animalism.” Philosophy Compass 10: 867-83.

Bailey, Andrew M. 2016. “Composition and the Cases.” Inquiry 59: 453-70.

Bailey, Andrew M. 2020. "Material Through and Through.” Philosophical Studies 177 (8): 2431-50.

Baron, Samuel. 2018. "A Formal Apology for Metaphysics.” Ergo 5.

Bartels, Daniel, Trevor Kvaran, and Shaun Nichols. 2013. "Selfless Giving." Cognition 129: 392-403.

Bennett, Karen. 2009. “Composition, Colocation, and Metaontology.” In Metametaphysics, edited by David Chalmers, David Manley, and Ryan Wasserman. Oxford: Oxford University Press.

Bennett, Karen. 2016. “There Is No Special Problem with Metaphysics.” Philosophical Studies 173 (1): 21-37.

Brenner, Andrew. 2015a. "Mereological Nihilism and the Special Arrangement Question." Synthese 192: 1295-314.

Brenner, Andrew. 2015b. "Mereological Nihilism and Theoretical Unification." Analytic Philosophy 56: 318-37.

Brenner, Andrew. 2017. "Mereological Nihilism and Personal Ontology.” The Philosophical Quarterly 67: 464-85.

Brenner, Andrew. 2018. "Science and the Special Composition Question." Synthese 195: 657-78.

Brenner, Andrew. Forthcoming. "Mereology and Ideology." Synthese.

Brogaard, Berit. 2004. "Species as Individuals." Biology and Philosophy 19: 223-42.

Brower, Jeffrey, and Michael Rea. 2005. "Material Constitution and the Trinity." Faith and Philosophy 22: 57-76.

Calosi, Claudio, and Gino Tarozzi. 2014. "Parthood and Composition in Quantum Mechanics." In Mereology and the Sciences: Parts and Wholes in the Contemporary Scientific Context, edited by Claudio Calosi and Pierluigi Graziani. Berlin: Springer.

Calosi, Claudio, and Matteo Morganti. 2016. "Humean Supervenience, Composition as Identity and Quantum Wholes." Erkenntnis 81: 1173-94.

Conee, Earl. 1999. "Metaphysics and the Morality of Abortion." Mind 108 (432): 619-46.

Contessa, Gabrielle. 2014. “One’s a Crowd: Mereological Nihilism without Ordinary-Object Eliminativism.” Analytic Philosophy 55: 199-221.

Copp, David. 1984. "What Collectives Are: Agency, Individualism and Legal Theory." Dialogue 23: 249-69.

Cowling, Sam. 2014. "No Simples, No Gunk, No Nothing.” Pacific Philosophical Quarterly 95 (2): 246-60.

Dorr, Cian. 2005. “What We Disagree About When We Disagree About Ontology.” In Fictionalism in Metaphysics, edited by Mark Kalderon. Oxford: Oxford University Press.

Dowland, S. Clint. 2016. “Embodied Mind Sparsism.” Philosophical Studies 173: 1853-72.

Ghiselin, Michael. 1974. "A Radical Solution to the Species Problem.” Systematic Zoology 23: 536-44.

Giberman, Daniel. 2018. "A Reason for the Non-Specialist to Care About the Metaphysics of Properties and Persistence." Inquiry: An Interdisciplinary Journal of Philosophy 61: 162-77.

Gilmore, Cody. n.d. Manuscript. "A Cartesian Argument against Compositional Nihilism."

Goldwater, Jonah. 2015. “No Composition, No Problem: Ordinary Objects as Arrangements.” Philosophia 43: 367-79.

Gould, Stephen. 2002. The Structure of Evolutionary Theory. Cambridge, MA: Harvard University Press.

Graham, Andrew. 2014. "Does Ontology Matter?” Disputatio 6: 67-91.

Greco, Daniel. 2015. "Verbal Debates in Epistemology.” American Philosophical Quarterly 52: 41-55.

Grimm, Stephen. 2011. “What's Interesting?” Logos and Episteme: An International Journal of Epistemology 2: 515-42.

\footnotetext{
${ }^{49}$ Arguments in Bennett (2016) are illuminating in this connection.

${ }^{50}$ For useful discussion of many issues in this neighborhood framed in terms of what is interesting, see Grimm (2011).
} 
Hawley, Katherine. 2014. Review of Empty Ideas: A Critique of Analytic Philosophy by Peter Unger. Notre Dame Philosophical Reviews. https://ndpr.nd.edu/news/empty-ideas-a-critique-of-analytic-philosophy.

Hawley, Katherine. 2017. “Social Mereology.” Journal of the American Philosophical Association 3: 395-411.

Healey, Richard. 2013. "Physical Composition." Studies in History and Philosophy of Modern Physics 44: 48-62.

Hirsch, Eli. 2011. Quantifier Variance and Realism: Essays in Metaontology. Oxford: Oxford University Press.

Hofweber, Thomas. 2016. Ontology and the Ambitions of Metaphysics. Oxford: Oxford University Press.

Horgan, Terence, and Matjaž Potrč. 2008. Austere Realism: Contextual Semantics Meets Minimal Ontology. Cambridge, MA: The MIT Press.

Hull, David. 1976. “Are Species Really Individuals?” Systematic Zoology 25: 174-91.

Hull, David. 1978. “A Matter of Individuality.” Philosophy of Science 45: 335-60.

Hull, David. 1980. "Individuality and Selection." Annual Review of Ecology and Systematics 11: 311-32.

Ismael, Jennan, and Jonathan Schaffer. 2020. “Quantum Holism: Nonseparability as Common Ground.” Synthese 197: 4131-60.

Kingma, Elselijn. 2019. “Were You a Part of Your Mother?” Mind 128: 609-46.

Korman, Daniel Z. 2016. Objects: Nothing Out of the Ordinary. Oxford: Oxford University Press.

Korman, Daniel Z. Forthcoming. “Why Care About What There Is?” In The Question of Ontology: The Contemporary Debate, edited by Javier Cumpa. Oxford: Oxford University Press.

Lewis, David. 1993. "Many, But Almost One." In Ontology, Causality and Mind: Essays on the Philosophy of D. M. Armstrong, edited by John Bacon, Keith Campbell, and Lloyd Reinhardt. Cambridge: Cambridge University Press.

Long, Joseph. 2019. “One's an Illusion: Organisms, Reference, and Non-Eliminative Nihilism.” Philosophia 47: 459-75.

Maclaurin, James, and Heather Dyke. 2012. "What Is Analytic Metaphysics For?” Australasian Journal of Philosophy 90: 291-306.

Marquis, Don. 1989. "Why Abortion Is Immoral.” The Journal of Philosophy 86: 183-202.

Maudlin, Tim. 1998. "Part and Whole in Quantum Mechanics." In Interpreting Bodies: Classical and Quantum Objects in Modern Physics, edited by Elena Castellani. Princeton, NJ: Princeton University Press.

Merricks, Trenton. 2001. Objects and Persons. Oxford: Oxford University Press.

McMahan, Jeff. 2002. The Ethics of Killing: Problems at the Margins of Life. Oxford: Oxford University Press.

Moreland, J. P., and William Lane Craig. 2009. “The Trinity.” In Oxford Readings in Philosophical Theology Vol. 1, edited by Michael Rea. Oxford: Oxford University Press.

Morganti, Matteo. 2009. "Inherent Properties and Statistics with Individual Particles in Quantum Mechanics." Studies in History and Philosophy of Modern Physics 40: 223-31.

Morganti, Matteo. 2013. Combining Science and Metaphysics: Contemporary Physics, Conceptual Revision and Common Sense. New York: Palgrave Macmillan.

Nichols, Shaun, Nina Strohminger, Arun Rai, and Jay Garfield. 2018. “Death and the Self." Cognitive Science 42: 314-32.

Olson, Eric T. 1997. The Human Animal: Personal Identity without Psychology. Oxford: Oxford University Press.

Olson, Eric T. 2003. “An Argument for Animalism.” In Defining the Beginning and End of Life: Readings on Personal Identity and Bioethics, edited by John P. Lizza. Baltimore, MD: Johns Hopkins University Press.

Olson, Eric T. 2007. What Are We? Oxford: Oxford University Press.

Plantinga, Alvin. 2007. “The Dawkins Confusion.” Books and Culture. http://www.christianitytoday.com/bc/2007/002/1.21. html.

Putnam, Hilary. 2004. Ethics without Ontology. Cambridge, MA: Harvard University Press.

Rhys Davids, T. W., ed. 1890. The Questions of King Milinda. Oxford: Clarendon Press.

Rea, Michael. 1998. "Sameness without Identity: An Aristotelian Solution to the Problem of Material Constitution." Ratio 11: 316-28.

Rettler, Bradley. 2018. "Mereological Nihilism and Puzzles about Material Objects." Pacific Philosophical Quarterly 99 (4): 842-68.

Rosen, Gideon, and Cian Dorr. 2002. “Composition as a Fiction.” In The Blackwell Guide to Metaphysics, edited by Richard Gale. Oxford: Blackwell.

Ross, Don, James Ladyman, David Spurrett, and John Collier. 2007. “In Defence of Scientism.” In Every Thing Must Go, edited by James Ladyman and Don Ross. Oxford: Oxford University Press.

Ruben, David-Hillel. 1983. "Social Wholes and Parts." Mind 92: 219-38.

Sandberg, Anders. 2013. "Feasibility of Whole Brain Emulation." In Philosophy and Theory of Artificial Intelligence Vol. 5, edited by Vincent C. Müller. Berlin: Springer.

Sāntideva. 1995. Bodhicaryāvatāra. Translated by Kate Crosby and Andrew Skilton. Oxford: Oxford University Press.

Schaffer, Jonathan. 2010. "Monism: The Priority of the Whole." The Philosophical Review 119: 31-76.

Sider, Theodore. 2009. “Ontological Realism.” In Metametaphysics, edited by David Chalmers, David Manley, and Ryan Wasserman. Oxford: Oxford University Press.

Sider, Theodore. 2011. Writing the Book of the World. Oxford: Oxford University Press.

Sider, Theodore. 2013. “Against Parthood." In Oxford Studies in Metaphysics Vol. 8, edited by Karen Bennett and Dean W. Zimmerman. Oxford: Oxford University Press. 
Siderits, Mark. 2015. Personal Identity and Buddhist Philosophy: Empty Persons. 2nd ed. Burlington, VT: Ashgate.

Snowdon, Paul F. 2014. Persons, Animals, Ourselves. Oxford: Oxford University Press.

Unger, Peter. 2014. Empty Ideas: A Critique of Analytic Philosophy. Oxford: Oxford University Press.

Thomasson, Amie. 2007. Ordinary Objects. Oxford: Oxford University Press.

Thomasson, Amie. 2015. Ontology Made Easy. Oxford: Oxford University Press.

van Fraassen, Bas. 2002. The Empirical Stance. New Haven, CT: Yale University Press.

van Inwagen, Peter. 1990. Material Beings. Ithaca, NY: Cornell University Press.

van Inwagen, Peter. 1996. "Materialism and the Psychological Continuity Account of Personal Identity." In Philosophical Perspectives 10: Metaphysics, edited by James Tomberlin. Cambridge: Blackwell.

Wilkins, Shane. 2016. “Why Paraphrase Nihilism Fails." Synthese 193: 2619-32.

Willard, M. B. 2013. "Game Called on Account of Fog: Metametaphysics and Epistemic Dismissivism." Philosophical Studies 164: $1-14$.

Cite this article: Bailey, A. M. and Brenner, A. 2020. Why Composition Matters. Canadian Journal of Philosophy 50: 934949, doi:10.1017/can.2020.52 